\title{
Russian military capabilities after 20 years of reform
}

\section{Bettina Renz (author accepted manuscript)}

Following the collapse of the Soviet Union, the newly independent Russian Federation's leaders faced the unenviable task of creating national armed forces on the basis of the obsolescent rump of the now defunct Soviet military. Plans for creating armed forces able to provide 'traditional' defence, in addition to dealing with the challenges of the post-Cold war security environment, were considered as early as 1992 and followed by a string of reform programmes over the course of the next two decades. The reform efforts were observed closely by analysts both in the West and in Russia, who have documented this drawn-out process in a large volume of literature. ${ }^{1}$ The assessment provided in the bulk of these works throughout much of the post-Soviet era was fairly unanimous: the reforms have failed, leaving the Russian armed forces 'impoverished, demoralized and largely ineffective', "woefully inadequate to address the country's security threats" ${ }^{3}$ and standing 'perilously close to ruin'.

Yeltsin-era rounds of reforms in particular were seen as botched jobs that merely reduced the number of troops, but essentially left the country with a smaller version of the Soviet-style mass conscription army. The latest push for change, announced in the aftermath of the 2008 war with Georgia, when the performance of the Russian military was widely criticised, got more positive press, at least initially. ${ }^{5}$ It was hailed by many as by far the most radical proposal for transformation to date. These reforms envisaged a comprehensive shift away from low-tech to high-tech; from conscription to professionalism; and from mass to mobility. Some structural changes, such as the transition from divisions to brigades and the consolidation of central command structures, were executed with impressive speed, raising expectations that Russia was finally on its way towards the acquisition of a 'modern' military. However, as time went on, observers noted a range of problems that dampened, in their eyes, the prospects for the reforms' ultimate success. The Russian defence industry still could not realistically produce the range and quality of cutting-edge equipment required for kitting out a modern military. The possibility of ending conscription and moving towards an all-volunteer force seemed as remote as ever. Moreover, the latest military doctrine adopted in 2010 continued emphasising the need for mobilization capacities, instead of focusing on mobility and rapid-reaction. When Defence Minister Anatolii Serdiukov was replaced in November 2012 by the long-standing Putin ally Sergei Shoigu, some observers went as far as to conclude that the 2008 reforms were now also, in fact, 'dead'. 6 
The Crimea crisis rudely thrust the state and capabilities of the Russian military into the centre of international attention. The decisiveness of Putin's actions left the rest of the world watch helplessly from the side-lines as Russian troops occupied the peninsula in preparation of the take-over following a hastily arranged referendum. Clearly, Russia's performance in Crimea gave lie to those who had argued over the past 20 years that failed reforms left Russia with a military that was ineffective and inadequate. What can explain this apparent gap between the perception and reality of Russian military reforms and capabilities in the $21^{\text {st }}$ century? This article argues that the perceived 'failures' of Russian military reforms and the presumed lack of suitability of its armed forces to face its $21^{\text {st }}$ century challenges in reality were never as clear-cut as often asserted. To an extent this is because the degree of change that did occur over the past two decades was underestimated. But more importantly, it is now clear that the very negative assessments of Russian military capabilities before the Crimea crisis were the result of flawed assumptions about the meaning of what 'successful' military reforms really mean in the context of contemporary Russia. In other words, analysts of Russian military reforms got it wrong, because they ignored the country's specific historical, political and strategic context and also failed to take into account the broader, international debates on the utility of military force in the $21^{\text {st }}$ century. This article offers this much needed context in reconsidering four commonly portrayed areas of 'failure' in Russian military reforms in light of the Crimea crisis: Russia's perceived failure to transform its armed forces into an ideal-type of 'modern' military fit for the $21^{\text {st }}$ century; the significance of its obsolete defence industry and resulting lack of cutting-edge technology; Russia's failure to abandon conscription in favour of a 'professional' military; and the maintenance of mass mobilisation capacities instead of moving towards smaller, mobile units. The article will show that Russia's successful mission accomplished in Crimea should not have caught us by surprise. The Russian armed forces were never as ill-suited to protect the country's security interests as often presumed and, as the Crimea crisis clearly demonstrated, Russia is a lot closer to having the army it needs than previously suggested.

\section{The myth of the 'modern' military fit for the $21^{\text {st }}$ century}

A crucial oversight in many analyses leading to hyperbolic assumptions about the state of the Russian military in the run-up to the Crimea crisis was the fact that the meaning of successful reform against which failure can be measured - or the question of what kind of army Russia really needs - is simply not obvious. Many analyses were based on the implicit or even explicit assumption that military reforms in Russia were, or at least ought to be aimed at the establishment of an ideal-type of 'modern' or even 'Western' military. In a 2004 article assessing the failure of 
Russian military reform, for example, Alexander Golts and Tonya Putnam asked why the Russian armed forces 'resisted efforts to change their structure and character in accordance with institutional arrangements operative in Western liberal democracies'? In their view, the failure of reforms was due, at least in part, to the fact that 'Russia's military elite has not acted forcefully to ensure military restructuring along Western lines'. 7 Similarly, a volume on Russian military politics published by the US Strategic Studies Institute in 2011 observed that 'there were no indications that Russia was moving towards a model of Western-style modern forces'. ${ }^{8}$ Some analysts studying Serdyukov's 2008 reforms also presumed that their aim was to establish 'a professional army of the Western model and "permanent readiness", 9 or even "designed to make the Russian Armed Forces look more like the United States/West'. ${ }^{10}$ It is true that proponents of reforms in Russia often referred to the same buzzwords commonly used in similar discussions in the West as demonstrated, for example, by the proliferation in recent years of references by top Russian military brass to network-centric warfare capabilities. ${ }^{11}$ And such synergies at least in the discourse should not come as a surprise, as military reforms in Russia are not occurring in a vacuum and conceptual interaction in military thinking between East and West is also nothing new. ${ }^{12}$ But the assumption that Russian military reforms were aimed at the establishment of a Western model of modern armed forces was flawed and problematic. First of all, similarities in discussions and policies are not the same as the explicit objective of remodelling the Russian armed forces along Western lines (and not surprisingly, no Russian doctrines or policies pertaining to military reform ever stated this to be the case!). Secondly, and more importantly, such an assumption was based on the rather questionable idea that there is such a thing as an 'ideal type' of modern armed forces, or at least a commonly accepted definition of what a military force fit for the $21^{\text {st }}$ century should look like.

A lack of a clear vision about where the Russian military ought to be going was often portrayed as a major reason for the failure of reforms. A study of doctrinal developments from 2010, for example, noted that 'the political leadership could or would not decide in which way military reforms were to go, either towards smaller, conventional, professional high-tech, expeditionary forces...or to continue with large but old-fashioned conventional forces together with modernized nuclear strategic-deterrent forces. ${ }^{13}$ This perceived lack of logic was often ascribed to a simple dichotomy of conflicting views. On the one side, there were predominantly civilian proponents of reform, wishing to move the Russian armed forces along a clearly defined path of transformation. On the other side, there were the conservative generals, 'stuck in the Cold War' and set on preserving the status quo: 'the problem is rooted in a fundamental conflict of interest between the government (that needs to tailor defence according to the international security environment...) and the General Staff 
(which does not want to part with its massive army). ${ }^{14}$ As this article will show, such explanations for the failure of reforms were simply too one-sided. They did not adequately reflect the complexity of challenges facing Russia in adjusting its armed forces not only to the changing security landscape, but also in matching military capabilities to the country's specific strategic context and vision (which, of course, differs from country to country). Even a cursory view at the international debates on contemporary war and military force demonstrate that the answer to the question of what successful military reform or transformation should entail is far from clear, and not only in Russia. Confronted by a changing international environment in the post-Cold war years Russia, like all other states, faced uncertainty over the implications this would have for its security and military posture. As is the case for all states, too, Russia's choices throughout the post-Soviet era were determined not only by considerations of military effectiveness, but constrained by a range of domestic factors, including historical, political and financial concerns. In other words, the idea that there was a single, one-size fits all approach for the creation of a 'modern' military that Russia simply failed to follow was flawed.

\section{The hype of modern military technology}

The presumed centrality of cutting-edge technology for successful military reforms is a case in point. Russia's failure to modernise its defence industry was often portrayed as a central obstacle to the process of military reform and the development of military capabilities suited to $21^{\text {st }}$ century warfare. ${ }^{15}$ It is true, of course, that repeated attempts at restructuring the sector since the 1990s did not produce decisive results and the technology gap between Russian and Western producers, especially in high-tech areas, continues to grow. Writing in 2012, the defence analyst Stephen Blank assessed in no uncertain terms the negative implications this would have for Russian military capabilities: 'the current ambitious effort to reform Russia's entire military structure to endow it with a high-tech military is imperilled and, along with it, Russia's overall strategic military capability... Clearly, the defence sector cannot produce the weapons Russia's Army needs' ${ }^{16}$ The Russian military's experience in the 2008 war with Georgia highlighted the lack of cutting-edge equipment, especially in the realm of information technology, but also regarding UAVs and precision munitions. ${ }^{17}$ And as Serdiukov himself acknowledged in the aftermath of the conflict, only ten percent of the armed forces' equipment at the time could be classified as 'modern', a share the 2008 reforms would seek to increase to 70 percent by $2020 .{ }^{18}$ The Russian defence industry's numerous problems, such as the lack of investment in $R \& D$, outdated management practices, a rapidly ageing workforce and an even older manufacturing base, have been extensively documented and do not need to be repeated here. ${ }^{19}$ And they have not escaped the attention of the Russian 
leadership, which has made them a priority in the 2008 reform plans. A range of measures, such as an increase in government defence orders and the allocation of additional resources to increase production capacity, have led to some improvements. Trying to catch up with the most advanced international technologies will be a long and drawn-out process, however, that cannot be achieved with quick-fix solutions. ${ }^{20}$ Of course, the continuing existence of important problems affecting the Russian defence industry is not in doubt. The point is, however that, as the ease with which Russia accomplished its mission in Crimea showed, sophisticated high-tech equipment was not as vital to the maintenance of Russian strategic ambitions and capabilities as previously presumed. And in contrast to those analysts pursuing this line of argument over the past 20 years this has long been recognised by 'conservative' Russian military thinkers, who have always rejected the idea that technology per se can revolutionise warfare and serve as a substitute for traditional military operations. $^{21}$

For a start, of course, the idea that the Russian defence industry is virtually on the verge of collapse should have been taken with a larger grain of salt. Although Russian producers clearly cannot compete internationally in the manufacture of information technology and electronics, the industry remained competitive throughout the post-Soviet era in many other areas, including the production of jet fighters, tanks, helicopters and submarines. It is also still strong enough to maintain an important position in the international market as the world's second largest arms exporter. ${ }^{22}$ Clearly, therefore, not only the Russian defence industry believes that the legacy systems it produces, and that are designed for the fighting of conventional state-on-state warfare, continue to have utility. But another important aspect of context was overlooked by analysts who equated the Russian military's lack of cutting-edge technology with a dearth of strategic military capabilities: the degree to which advanced technology should be seen as the key to solving conflicts is far from clear not only in Russia, but even in countries with highly developed and sophisticated professional militaries, including the United States. There was perhaps a brief moment of apparent clarity at the beginning of the 1990s. During the 1991 Gulf war the world was stunned to witness US military forces deploying previously unseen technologies that allowed them to achieve military victory in record time and with next to no need for risking its soldiers on the ground in traditional battle. Subsequent debates on military transformation in the US and elsewhere centred on the move from quantity to quality, where technological sophistication and precision would allow for dramatic cuts of the armed forces. ${ }^{23}$ The experience of the US military in Iraq seemed to offer a war-winning formula to serve as a guide to others for successful military reform. This formula became known as the socalled Revolution in Military Affairs (RMA), where ever more sophisticated technology would 
enable states to network their forces into a 'system of systems' that could overcome the 'fog of war' and provide an answer to any political and strategic problem. But as is well known, it did not take long for world events to interfere with this apparently perfect solution. Protracted ethnic conflicts in the Balkans throughout the 1990s and the drawn-out wars in Afghanistan and Iraq started sowing doubts in the minds of many about the virtues of undue technological optimism. ${ }^{24}$ Criticism of the merits of the revolution in military affairs and of related techno-centric concepts, such as networkcentric warfare, became increasingly common. ${ }^{25}$ Calls were made by some to 'transform transformation' away from the focus on technology and superior firepower and for a reorientation back towards the need for 'boots on the ground'. ${ }^{26}$

Within this in mind, a closer look at the relative failures and successes of Russian military operations before the Crimea crisis would have showed that the lack of sophisticated technology in and of itself did not amount to the collapse of military capabilities or the outright 'failure' of reforms. It is highly unlikely, for example, that more high-tech equipment or even full networkcentric warfare capabilities would have led to fundamentally different strategic results in Russia's Chechen wars or in its conflict with Georgia in 2008. The first Chechen war from 1994-96 was an unambiguous military failure that concluded in the granting of de-facto independence to the rebellious republic. Some tactical and operational lessons learned led to improvements in the Russian military's performance during the second Chechen war launched in 1999, but this, too, turned into a protracted conflict. ${ }^{27}$ The failures of the Russian military in their conduct of the Chechen wars were, of course, manifold and they have been well documented elsewhere. But suffice it to say that it was not the lack of high-tech sophistication that was held responsible for failure in these cases. Instead, fingers were pointed at excessive use of force and the Russian military's structural and doctrinal unpreparedness for engaging in counterinsurgency warfare. ${ }^{28}$ Yes, the use of dumb bombs for the destruction of Grozny caused an excess in civilian deaths that could, at least in theory, have been reduced with more precision weapons. Moreover, cutting-edge command-and-control systems and better kit for Russian troops would have probably brought down the number of soldiers killed. But as desirable as this would have been, it is unlikely that better equipment would have averted the strategic failure of these campaigns. We only need to look at the wars in Afghanistan and Iraq, where US coalition forces got bogged down in protracted conflicts in spite of having the world's most advanced military technology at their disposal. Whilst these conflicts are not fully comparable to the Chechen wars, they nonetheless demonstrate that technology is not a panacea for all circumstances, especially when an insurgency is involved. 
Following Russia's war with Georgia in 2008, much was made of the failures of the Russian armed forces, especially when it came to shortcomings in C4ISR. Outdated or absent technology was held responsible for having caused an excess in Russian combat deaths and several aircraft were lost to blue-on-blue incidents as a result of the pilots' inability to communicate with troops on the ground. Russia's experience in Georgia underscored the failure of previous military reforms in the eyes of many and it also served as the impetus for the announcement of Serdiukov's radical 2008 reform plans that emphasized the need to modernize weapons and equipment. ${ }^{29}$ As already mentioned, the development of network-centric warfare capabilities turned into a central talking point of reform and featured increasingly prominently in statements made by the top military brass. ${ }^{30}$ However, the strategic significance of Russian military failures in Georgia owing to the lack of high-tech equipment was clearly overstated. At the end of the day, the Russian military quickly succeeded in ejecting Georgian forces from South Ossetia and Abkhazia and was able to withdraw from the rest of Georgia within a matter of five days. It seems fair to say that this is not a mean feat by the standards of any military and it demonstrated that by 2008 that the Russian army was not quite as inadequate or close to ruin as some people believed. More high-tech equipment might have allowed it to execute the operation even more quickly and with fewer casualties and aircraft lost. However, it was clearly not essential in this case for the achievement of strategic victory.

The Russian troops' effective conduct and performance in Crimea indicated that further progress had been made since the Georgia war in improving command and control and inter-service coordination. Observers also noted the use of more 'modern' kit that had previously been absent, such as new load-carrying equipment and personal radios. But it is also clear that Russia did not achieve its strategic objectives in Crimea simply because of better technology or because it was now 'a more Western-looking army'. ${ }^{31}$ After all, during the Crimea crisis the mere deployment of a few units of uniformed men carrying rifles and some posturing involving outdated military vehicles and naval vessels was sufficient to prevent both the Ukrainian interim authorities and their allies from interfering with Moscow's plans. Clearly, the success of this mission was not hindered by Russia's technology gap with Western militaries and the lack of cutting-edge equipment. Simply speaking, from a strategic perspective the objectives of the Georgian conflict and the occupation and take-over of Crimea were achievable by the use, or threat thereof, of military force, whereas the objectives of the Chechen wars were not. But this was a matter of the strategy on which the operations were based, and not a question of technological sophistication.

Of course, this is not to say that Russian military reformers, and probably even the most conservative of Russian military generals, do not see up-to-date equipment and even fully-blown 
C4ISR capabilities as desirable or important. After all, the Russian military's inability to acquire domestically the equipment now seen as standard in the West led to one of the most notable developments in Russian defence procurement over the past few years: for the first time in the country's recent history it turned to foreign imports in an attempt to close technology gaps. ${ }^{32}$ As none of Russia's allies within the former Soviet space are in a position to supply the latest in military equipment, foreign purchases were made from countries with which Russia has not traditionally maintained a close relationship. Such purchases have included Israeli UAVs, armoured vehicles from Italy and the well-known plans to procure Mistral-class landing vessels from France. The Crimea crisis, of course, will inevitably close Russia's access to Western advanced military technology, at least for the foreseeable future. A range of countries, including the US, UK and Germany, are discussing the cancellation of military contracts and France has threatened to back out of the Mistral deal as sanctions against Russia continue taking hold. But given the above discussion, the implications of this for the future of Russia's military should not be exaggerated. As the Crimea crisis clearly demonstrated - to the world and to Putin's government - the centrality of cutting-edge technology for the maintenance of the Russia's strategic military capabilities is at best a matter for debate. As such, it is highly doubtful whether these sanctions will coerce the Russian leadership into changing tack.

\section{What kind of army does Russia need?}

Another mistake in many analyses of Russian military reforms before the Crimea crisis was the failure to address one crucial question: what kind of army Russia really needed and wanted, given its specific strategic context and priorities. Observers of Russian military reforms over the past twenty years simply took it for granted that the Russian military needed to abandon conscription and mobilization capacities in favour of smaller units that are "mobile, flexible and professional and, therefore, combat-ready for scenarios like local conflicts and asymmetrical warfare'. ${ }^{33}$ As Zoltan Barany asserted in 2005, the outmoded practice of conscription and mobilisation simply was incompatible with the 'small-scale soft security threats [Russia] should anticipate in the foreseeable future'. ${ }^{34}$ Efforts towards this end, in the eyes of many observers, were being stymied, however, by 'hardliners' in the Russian military sticking to 'the old concept of a mass-mobilization army, partly due to traditional threat perceptions and partly due to bureaucratic interests'. ${ }^{35}$ Again, a conflict between reformist civilians and conservative military leaders was held responsible for the perceived ambiguities in Russian military thinking. When the latest military doctrine was published in 2010, analysts noted that on the one hand, it 'stated characteristics of modern warfare, but on the other stressed mobilization capabilities'. ${ }^{36}$ But as was the case with the issue of high-tech equipment 
discussed above, Russia's perceived need to 'reform its military into Western-style expeditionary forces ${ }^{37}$ was not straightforward and its failure to move into this direction cannot be accounted for simply by the opposition from conservative generals. Again, such conclusions neglected important aspects of context, three of which will be discussed in the remainder of this article. First of all, the presumption that 'soft' threats and asymmetric wars are now the dominant form of conflict for which successful military reforms must prepare was too simplistic. Second, the notion that the practice of conscription per se was incompatible with a modern military able to uphold Russia's strategic military capabilities was a misconception. Finally, a closer look at Russia's specific strategic context belies the idea that Russian military reforms were ever meant to result in a major reorientation towards 'new' wars or asymmetric warfare and the creation of small, mobile units trained specifically for this purpose.

\section{The shape of future war?}

It is clear that something about the character of war has been changing, but, as the Crimea crisis clearly demonstrated, the exact nature of these changes and their implications for the utility of military force remain a matter of debate. Much of the scholarship on war over the past two decades was characterized by categorical assertions of unprecedented newness and 'historic rupture' in advancing the notion that "contemporary wars are "substantively distinct" from older patterns of armed conflict'. ${ }^{38}$ Such stark reactions were certainly understandable in the immediate aftermath of dramatic and unexpected international events like the end of the Cold War and 9/11. However, with the benefit of hindsight, some analysts in recent years started voicing disquiet about what they perceived as the overly simplistic interpretation of these changes' implications. In particular, the portrayal of a straightforward dichotomy between 'new wars' and an ideal-type of now defunct 'old', conventional interstate warfare characterizing the Cold War years was criticized for lacking historical and international contextualization long before the Crimea crisis occurred. ${ }^{39}$ The strategist Hew Strachan, for example, cautioned in 2011 that the perception of 'traditional' interstate war as a relic of the past is both short-sighted and highly questionable. And, as Russia's actions in Crimea clearly showed, he was not wrong. It is one thing to observe that the threat of interstate war appears remote in specific regions of the world at a certain moment in time. However, as Strachan pointed out, it is quite another thing to conclude from this that the same is true forever and on a global scale: 'to extrapolate... from either an American context or a European one to the rest of the world, to Asia and Africa in particular, seems fanciful... Moreover, those whose thinking is shaped by the Western tradition have almost no historical evidence to support a belief in the obsolescence of certain sorts of war, despite its near orthodoxy. ${ }^{40}$ 
Other analysts also argued in recent years that the 'near orthodoxy' of the belief in small wars and insurgencies as the epitome of modern conflict could have negative long-term consequences, because of the real-life policy changes it could bring or already has produced. As Gian Gentile, the director of military history at the US Military Academy argued in 2009, the US armed forces' focus on counterinsurgency turned into a 'dogma' that is 'not simply dangerous; it neglects key aspects of U.S. national security' and risks losing the military's capacity 'to conduct operations at the higher end of the conflict spectrum'. ${ }^{41}$ In a similar vein, the UK army's Chief of General Staff in the same year called for a continuation of the British military's capacity to engage 'in high-intensity interstate-type warfare' at the same time as 'keeping alive the "conceptual flame" of manoeuvre warfare'. ${ }^{42}$ The events in Crimea clearly vindicated such warnings not to consign the possibility of 'traditional' interstate war to the dustbin of history prematurely. The above discussion is not intended to settle the 'new' versus 'old' wars debate, which, in any event, is far too complex to do justice to within the confines of this article. But it serves to demonstrate the point that apparent 'ambiguities' in military thinking exist not only in Russia and the situation throughout the postSoviet era has been considerably more complex than simply 'hardliners' standing in the way of a clearly paved path towards successful reform. Interestingly, Gentile noted that arguments in favour of maintaining 'traditional' war-fighting capabilities in the US - like in discussions of Russian military reform - are often dismissed as the conservative mindset of military generals wishing 'to recreate the old Soviet Union so we can fight the Second World War all over again'. He rejected such criticism as a one-sided reading of this argument: 'the army does need to transform from its antiquated Cold War structure toward one that can deal with the security challenges of the new millennium... [But] the future of war is not only counterinsurgencies such as Afghanistan or Iraq. One can imagine a range of possibilities that cover the full spectrum of war and conflict' ${ }^{43}$ It is within this context that Russia's decision to maintain conscription, mobilisation capacities and a strong nuclear deterrent at the same time as modernising its military in other areas should have been understood.

Russia's strategic context: preparing for 'old' or 'new' wars?

The Crimea crisis clearly vindicated Strachan's point above about the importance of strategic context. Extrapolating from Western strategic priorities, many analysts assumed that Russian military reforms had failed because they did not prepare the armed forces for 'new-war type' scenarios and the fighting of complex overseas contingencies and counterinsurgency campaigns like Afghanistan and Iraq. Russia's performance in Crimea would have come as less of a surprise if the country's specific strategic context had been taken into account more explicitly. As a matter of fact, 
'new-war type' scenarios were never central to Russia's strategic vision and, in contrast to many Western states, expeditionary warfare, overseas contingencies and humanitarian interventions are tasks Russian foreign policy and military doctrine explicitly do not intend the armed forces to get involved in. ${ }^{44}$ Russian security policies and military doctrines throughout the post-Cold War era on the one hand did reflect an increasing appreciation of the changing security environment with 'soft' threats and human security issues, including terrorism and other organised transnational crime, illegal migration and even environmental issues making their way into official documents. The Russian leadership also recognised "that "new" transnational threats can be non-military in nature and may require non-military and international rather than state-led responses". ${ }^{45}$ But, on the other hand, 'new-war type' scenarios and 'soft' security threats were never seen in Russia as the only or most important priority and military doctrine continued emphasising more traditional threats and capabilities in addition to 'modern' warfare. ${ }^{46}$ From a strategic point of view, the prioritisation in Russia of a multitude of threats and military capabilities makes a good deal of sense, bearing in mind the country's geopolitical position and also its feeling of relative 'strategic solitude' compared to most states in the West. ${ }^{47}$ Capabilities for dealing with 'new-war type' scenarios like ethnic conflicts, insurgencies and terrorism might dominate alongside Russia's southern flank, in the Caucasus and Central Asia. But in the east, the country is bordering China with its 'multi-million troop army using traditional approaches to the conducting of combat operations...with a great concentration of manpower and firing systems'. This fact alone makes the maintenance of some mobilisation capacities and an element of conscription appear rather rational from a strategic planning point of view. In the West, Russia is facing NATO's numerically and technologically superior 'innovative armies with non-contact forms and methods for using the latest forces and equipment', which Russia could not match in a conventional war. ${ }^{48}$ Russia never made it a secret that NATO's post-Cold war activities have long been perceived as a security threat and as an encroachment on the country's regional interests. ${ }^{49}$ The latest Russian military doctrine adopted in 2010 explicitly named NATO 'out-of-area' operations and eastward enlargement high on the list of military dangers to the country. ${ }^{50}$ This strategic context gives meaning to what many analysts before the Crimea crisis interpreted as Russia's seemingly illogical, concurrent pursuit of a modern military, 'old-fashioned' mobilisation capabilities and nuclear deterrence. 'Traditional' perceptions of potential enemies and conflicts left a mark on Russian military doctrine and foreign policy throughout the post-Soviet era. But it was a mistake to interpret this simply as the inability of Russian generals to move on. Not only because a healthy degree of 'paranoia', is required of the armed forces of any state in their pursuit of the unenviable task to 'think the unthinkable' and to prepare for an uncertain future where it is plausible to presume that 'much that is unpredicted and 
unpredictable can and will occur. ${ }^{51}$ But also because Russia's strategic vision never envisaged a major reorientation towards a future dominated by 'new war-type' scenarios in the first place.

\section{Continued conscription as a deal-breaker for reform?}

The establishment of an all-volunteer force is not strategically expedient for Russia and, in any case, it has also been impossible for a variety of other political and societal reasons. After all, military effectiveness is not the only reason why countries opt for a particular recruitment system, and not only in Russia. Whilst military effectiveness is an important consideration, a confluence of other factors, including economic arguments and domestic political constraints have also influenced the decision of states to maintain or abandon conscription when the Cold War ended. ${ }^{52}$ As a result, although the general post-Cold war trend has been towards professional armed forces, a number of highly developed countries also continue to maintain conscription and some capacity for mobilisation, including Finland, Norway, Denmark and Israel. ${ }^{53}$ Those countries rely on a combination of recruitment systems, allowing them to maintain both the technological expertise and other professional skills required for the conduct of modern combined armed operations, as well as an element of conscription and mobilisation for situations where greater numbers of infantry solders might be needed. ${ }^{54}$ In addition to strategic considerations a confluence of political, societal and economic factors has meant that the outright abolishment of conscription in Russia, too, continues to be a highly unlikely prospect, at least for the foreseeable future. These factors include the conviction that a large reserve is essential and also the conservative belief, which is not only prevalent in Russia, that conscription should be maintained as an instrument for the transmission of patriotic values or as a so-called 'school of the nation'. ${ }^{55}$ But Russia's decision not to abandon conscription following the end of the Cold War is more complex than merely the result of interference by conservative generals in the civilian leadership' strategic deliberations.

As Rod Thornton concluded from his analysis of reforms during the Yeltsin era, 'the principal political goals in terms of ending conscription...were not so much to develop a more efficient military - although that would have been a welcome side-effect - rather, Yeltsin wanted to both save money and to court electoral popularity'. ${ }^{56}$ The latter factor is particularly poignant and was an important driver behind the push by any Russian politician for a professional military over the past two decades. Reasons for the low esteem of conscript service in Russia are well known. In addition to the fate suffered by many young draftees during the first Chechen war this 'image problem' results from poor conditions of service and in particular the notorious dedovshchina, a brutal practice of hazing and violence against soldiers with sometimes fatal results. ${ }^{57}$ The persistent 
unpopularity of conscription meant that promises of a move towards an all-volunteer force were as politically expedient under Yeltsin as they are today. ${ }^{58}$ But the wish to phase out conscription for political reasons, no matter how genuine it might have been at any point during the past two decades, has not translated into an easily workable plan for such an undertaking. After all, the low prestige of military service in Russia is not limited to conscription alone. The architects of the 2008 reforms were painfully reminded of this fact when plans for the creation of a corps of professional sergeants faltered because of the inability to sign up 'quality' volunteers in sufficient numbers. ${ }^{59}$ The poor image of military service in addition to Russia's demographic problems means that the country will continue to struggle recruiting the number conscripts it needs, let alone the amount of soldiers required for a fully professional force. ${ }^{60}$ For this reason alone the consignment of conscription to the dustbin of Russian history is not on the horizon. In 2010 a Russian journalist urged that 'changing the image of the army and reversing the negative attitudes towards military

service is the most urgent task of military transformation'. ${ }^{61}$ A number of measures taken in recent years (the so-called programme of 'humanising service conditions' for conscripts and professional soldiers and significant rises in salaries paid to military personnel) ${ }^{62}$ indicate that the Russian leadership has finally started heeding this advice. But only time will tell if their endeavours will succeed. The unreformed system of conscription and general image problem of military service in Russia continues to pose a major problem to the Russian military that will require serious strategic attention, resources and political will. But the continued practice of conscription per se was never a deal breaker for the transformation of the army into a force fit for the $21^{\text {st }}$ century. After all, conscription as a recruitment system of the armed forces 'is not dead as a political idea' and it 'regularly reappears on the agenda' even in states that have long since done away with the practice. ${ }^{63}$ This is true even for the US, for example, where General Stanley McChrystal suggested 'bringing back the draft' in order to share the military burden more equitably across American society as recently as $2012 .^{64}$

\section{Professional rapid-reaction forces in the context of Russia}

The maintenance of conscription, mobilisation capacities and a strong nuclear deterrent in Russia has not been incompatible with military modernisation in other areas and the creation of more permanent-readiness units manned entirely by professional soldiers. The performance of Russian troops in Chechnya, and to an extent in Georgia, had clearly demonstrated to the Russian political and military leadership the need to strengthen rapid-reaction capabilities for dealing effectively with conflicts at the lower end of the spectrum erupting along Russia's periphery. And it is indeed the recognition of this need that was at the heart of the post-2008 reforms. However, the Crimea 
The effective performance of rapid-reaction units in all kinds of scenarios, of course, is not guaranteed by 'professionalisation' alone. Congruent adjustments in doctrine and thinking are also required to make such units fit for deployment, especially in conflicts requiring more than 'conventional' war-fighting skills. For example, although operational and tactical changes allowed Russian forces during the second Chechen war to improve their effectiveness in controlling and holding Chechen territory, this did nothing for the achievement of a long-term political solution. This was because handling the insurgency as a tactical issue without considering the strategic implications meant that Russian troops were not ready 'specifically to handle the problems associated with guerrilla war'. ${ }^{65}$ Modernising the education and training of officers and soldiers for permanent readiness indeed has been a part of the recent reform efforts. As Makarov asserted in 2011, this process included 'the reworking of all guidance documents, instructions, regulations and teaching aids'. Although relevant materials were rewritten several times Makarov did not consider the results satisfactory, because they were still, in his view, too much 'geared towards past wars'. ${ }^{66}$

Did lip-service paid to the need for conceptual changes translate into substantially new approaches to doctrine and training for 'new wars' in Russia? Who knows. But perhaps the answer to this question is not even that important, because two things are certain: first, Russia is unlikely to have been more successful than other states in trying to find a winning formula for fighting counterinsurgency by military force. ${ }^{67}$ Second, and more importantly, the Crimea crisis demonstrated yet again that analyses of Russian military reforms disregarded the country's strategic context and extrapolated from the Western experience. Yes, the establishment of effective rapid reaction forces was an important aspect of the 2008 reforms. But these units in Russia were never intended for expeditionary warfare or predominantly for overseas counterinsurgency or counterterrorism operations in the Western understanding of the term. Instead, according to the former Chief of the General Staff, Nikolai Makarov, the 2008 reforms envisaged the creation of further permanent readiness units staffed entirely by professional soldiers for deployment alongside Russia's volatile borders, whilst the mixed system of recruitment would continue for staffing in 'calmer' areas. ${ }^{68}$ In this regard, Russian military planners drew on the experience of the airborne forces, which have had under their command a number of fully professional elite regiments since 2002. It was these troops that stood out in the Georgia war for their professionalism, fast response, training and fighting skills, especially in comparison to regular infantry troops. ${ }^{69}$ The same rapidreaction airborne troops were also observed to act effectively in the Crimea operations and in cooperation with other 'elements from the special forces reconnaissance brigades and the marine infantry'. Russia's successful mission accomplished in Crimea demonstrated that the 2008 reform 
objective to strengthen the country's rapid reaction capabilities for deployment to trouble spots in Russia's near abroad was achieved effectively.

Finally, analyses of Russian military reform over the past twenty years failed to take into account another aspect of context in their assessment of the country's perceived lack of progress in creating forces able to deal with small-scale 'soft' security threats. An important puzzle of military transformation facing the US and other Western militaries has been the question of how to maintain armed forces that are able to deal with all missions on the contemporary 'spectrum of conflict', ranging from large-scale interstate warfare to humanitarian relief operations. Current US and UK military doctrine, for example, is based on the premise that the capacities of armed forces trained and equipped for engaging in high-intensity, interstate conflicts can be adapted 'down and across' to missions on the lower end of the conflict spectrum. Given the extent of involvement in interventions and stabilization operations over the past two decades, however, doubts have been raised in some quarters about the sustainability of this idea. ${ }^{70}$ Perceived challenges include abovementioned fears that all-purpose forces would lose the prowess for 'fighting heavy'. Others questioned whether 'traditional' military culture would prevent soldiers from ever seeing post-Cold war missions as more than a diversion from their core professional activity; ${ }^{71}$ or if the service cultures of military and civilian actors having to cooperate in stabilization operations were too incompatible to ever allow a truly comprehensive approach. ${ }^{72}$ As Gentile concluded in his article above, the quest to 'build an army to win all wars' would not be easy. One way of overcoming the problems associated with the use of conventional troops in military operations other than war would be the creation of separate units dedicated to specific missions, as suggested, for example, by Kevin Stringer in his alternative vision for the US military. As he himself acknowledged, however, such a drastic approach to transformation would be likely to be met with resistance as it runs counter "to the wider [US] Army culture' ${ }^{73}$ Stringer's alternative remains on the margins of Western debate, yet the core of his idea, by contrast, is far from radical within the context of contemporary Russia. Although the issue has been rarely ever raised in discussions of military reform and capabilities, the country already has a number of armed units dedicated to specific missions at the lower end of the conflict spectrum.

In addition to the army, navy, air force and Strategic Rocket Forces under the Ministry of Defence, a number of institutionally distinct Russian 'power ministries' are specializing in smaller-scale and 'soft' security threats. The fight against terrorism, for example, is one of the many tasks of the Federal Security Service (FSB). Towards this end, the service maintains special-assignment units with military training and the right to procure corresponding weapons and equipment. These units 
have been fighting alongside regular forces and troops of the Interior Ministry in both Chechen campaigns. They were also heavily involved in the counterterrorist operations ending the hostage crises in a Moscow theatre and the Beslan school in 2002 and 2004 respectively. When a lack of coordination in counter-terrorism responses was identified as a major reason for the poor performance of Russian forces particularly in Beslan, a National Counter-Terrorism Committee uniting all involved ministries and headed by the director of the FSB was created in 2006. The Russian Federal Service for the Control of the Drugs Trade (FSKN) was established in 2003. Being in charge of reducing the demand and supply of illegal drugs in Russia and beyond, the service has under its command special-assignment units that have been fighting alongside military personnel against drug crime committed by insurgent groups in the North Caucasus, including in Chechnya. Although the FSKN's performance has attracted a fair share of criticism, it has contributed to responses to large-scale drug crime on an international level, for example, in the form of joint operations with US military personnel and Afghan counternarcotics forces raiding drug laboratories in Afghanistan. Another pertinent example of smaller-scale contingency units is the Ministry for Civil Defence and Emergency Situations (MChS) and its civil-defence troops. Their central task is to assist civilian populations in humanitarian crisis situations both in Russia and abroad. Being armed and trained for the purpose of self-defence, these 'hybrid' troops can overcome the abovementioned problems usually associated with the involvement of conventional forces in humanitarian relief and reconstruction efforts. MChS troops have contributed extensively to humanitarian operations under the umbrella of the UN High Commissioner for Refugees, the World Food Programme, the UN Development Programme and UN Mine Action Service. They have also previously participated in numerous training exercises for disaster response and management with NATO troops. ${ }^{74}$ This does not mean, of course, that Russia has found the golden key to success in dealing with 'soft' security threats. But it shows that the need for its 'regular' armed forces to develop capabilities beyond the 'traditional' tasks of defending the country's territory and population against external threats is not as imperative as often implied. The power ministries and the tasks that they fulfil - some more successfully than others - should have been factored into discussions of Russian military capabilities throughout the post-Soviet era even if they did not easily fit into a Western framework.

In sum, the Crimea crisis clearly demonstrated that the story of Russian military reforms and capabilities was never as black and white as we were often led to believe. As a result of flawed assumptions about what a 'modern' Russian military should entail, its inadequacies to address the country's security threats were exaggerated, just as the degree of change that actually had occurred 
over the past two decades was played down. For the last twenty years, in spite of its difficulties, the Russian military addressed the country's security threats when it was tasked to do so by the political leadership. It deployed troops to a number of local and regional conflicts and deterred potential threats from further afield in maintaining a strong nuclear arsenal. Of course, the performance of the Russian armed forces when used in combat has been far from stellar and their conduct especially in Chechnya deserved every ounce of criticism received. At the same time, it is only fair to point out that the 'failure' of counterinsurgency approaches is not unique to Russia and Russian troops were considerably more effective in Georgia and Crimea, where military means matched the conflicts' strategic ends. Russia's mission accomplished in Crimea caught many by surprise and the episode is likely to revolutionise Western views of the Russian military in the longer term. But observers and policy makers should be cautious not to flip from one extreme to another in their assessment of Russian military reforms and capabilities. The well-coordinated actions in Crimea certainly demonstrated that within the framework of the Russia's strategic context and for the purposes of protecting its interests in the 'near abroad' the country's military is lot more effective and capable than previously presumed. But we cannot extrapolate from the relative success of the Crimea operation - and let's not forget that it did not involve any actual fighting - that Russia would be capable of replicating similar scenarios beyond it's 'near abroad' or even in open confrontation with NATO. Such a conclusion might be convenient to those with a vested interest in increasing European spending on defence. But it is unrealistic given the multitude of problems the Russian military continues to face and that will require both long-term strategic attention and focused resources. Now is the time to abandon hyperbolic portrayals of Russian military might or decay.

\section{Acknowledgements:}

This article was written during a visiting scholarship at the University of Helsinki's Aleksanteri Institute within the framework of the Finnish Centre of Excellence in Russian Studies - Choices of Russian Modernisation. I would like to thank everybody at the Aleksanteri Institute for their friendship and support, I had a wonderful time. I am also grateful to Edwin Bacon, Barbara Falk and Sibylle Scheipers for reading and commenting on an earlier draft of this article. 
${ }^{1}$ Anne C. Aldis and Roger N. McDermott (eds.), Russian Military Reform: 1992-2002 (London: Frank Cass, 2003); Alexander Golts, Armiia Rossii: 11 Poteriannykh Let (Moscow: Zakharov 2004); Carolina Vendil Pallin, Russian Military Reform: A Failed Exercise in Defence Decision Making (London: Routledge 2009).

2 Zoltan Barany, 'Defence Reform, Russian Style: Obstacles, Options, Opposition', Contemporary Politics 11/1, 2005, 33.

${ }^{3}$ Alexander Golts and Tonya Putnam, 'State Militarism and its Legacies: Why Military Reform has Failed in Russia', International Security, 29/2, 2004, 121.

${ }^{4}$ Alexei Arbatov, 'Military Reform in Russia: Dilemmas, Obstacles and Prospects', International Security, 22/4, 1998, 83.

${ }^{5}$ For example, Roger McDermott; Bertil Nygren, and Carolina Vendil Pallin (eds.), The Russian Armed Forces in Transition: Economic, Political and Institutional Uncertainties (London: Routledge 2012).

${ }^{6}$ Roger McDermott, 'Putin Considers New 'Defence Plan' as 'Reform' Dies', Eurasia Daily Monitor, 10/21, 5 February 2013.

${ }^{7}$ Golts and Putnam, 'State militarism', 121 and 124.

${ }^{8}$ Stephen Blank (ed.), Russian Military Politics and Russia's 2010 Defense Doctrine (Carlisle, PA: Strategic Studies Institute 2011), 27.

${ }^{9}$ Gregory P. Lannon, 'Russia's New Look Army Reforms and Russian Foreign Policy', The Journal of Slavic Military Studies, 24/1, 2011, 38.

${ }^{10}$ Charles K. Bartles, 'Defense Reforms of Russian Defense Minister Anatolii Serdyukov', The Journal of Slavic Military Studies, 24/1, 2011, 76.

${ }^{11}$ Roger N. McDermott, 'Russian Perspective on Network Centric Warfare: The Key Aim of Serdyukov's Reform', US Military Foreign Military Studies Office Report, 2010. <http://fmso.leavenworth.army.mil/Collaboration/international/McDermott/Network-Centric-Warfare.pdf>, 5.

${ }^{12}$ Dima Adamsky, 'Through the Looking Glass: The Soviet Military Technical Revolution and the American Revolution in Military Affairs', The Journal of Strategic Studies, 31/2, 2008, 257-294.

${ }^{13}$ Marcel DeHaas, 'Russia's Military Doctrine Development' in Blank, Russian Military Politics, 27.

${ }^{14}$ Barany, 'Defence Reform', 35.

${ }^{15}$ Irina Isakova, 'The Russian Defense Reform', China and Eurasia Forum Quarterly, 5/1, 2007, 79.

${ }^{16}$ Stephen Blank, 'A work in regress? Russian defense industry and the unending crisis of the Russian state' in McDermott et al (eds.), The Russian Armed Forces in Transition, 156-7.

${ }^{17}$ Carolina Vendil Pallin and Fredrik Westerlund, 'Russia's War in Georgia: Lessons and Consequences', Small Wars and Insurgencies, 20/2, 2009, 401.

${ }^{18}$ Margarete Klein, 'Russia's Military Capabilities: “Great Power” Ambitions and Reality', Berlin: Stiftung Wissenschaft und Politics Research Paper 12, 2009, 9.

${ }^{19}$ For example, Julian Cooper, 'Developments in the Russian Arms Industry,' in SIPRI Yearbook (Oxford: Oxford University Press 2006), 431-32; Julian Cooper, 'Military Procurement in Russia' in McDermott et al (eds.), The Russian Armed Forces in Transition. 
${ }^{20}$ Fredrik Westerlund, 'The Defence Industry' in Carolina Vendil Pallin (ed.), Russian Military Capability in a Ten-Year Perspective (Stockholm: Swedish Defence Research Agency Report No. FOI-R-R-3474-SE, 2012), 90.

${ }^{21}$ Tor Bukkvoll, 'Iron Cannot Fight - the Role of Technology in Current Russian Military Theory', Journal of Strategic Studies, 34/5, 2011,687-691.

${ }^{22}$ Westerlund, 'The Defence Industry', 87.

${ }^{23}$ Olof Kronvall, 'Transformation: The Key to Victory?' in Karl Erik Haug and Ole Jørgen Maa $\varnothing$ (eds.) Conceptualising Modern War (London: Hurst \& Company 2011), 29.

${ }^{24}$ Stephen Biddle, 'Victory Misunderstood: What the Gulf War Tells us about the Future of Conflict', International Security, 21/2, 1996, 139-179.

${ }^{25}$ Tim Benbow, The Magic Bullet? Understanding the Revolution in Military Affairs (London: Brassey's 2004).

${ }^{26}$ Elinor Sloan, Military Transformation and Modern Warfare (Westport, CT: Praeger Security International 2008).

${ }^{27}$ Quentin Hodgson, 'Is the Russian Bear Learning? An Operational and Tactical Analysis of the Second Chechen War, 1999-2002', The Journal of Strategic Studies, 26/2, 2003, 64-91.

${ }^{28}$ Mark Kramer, Guerrilla Warfare, Counterinsurgency and Terrorism in the North Caucasus: the Military Dimension of the Russian-Chechen Conflict', Europe-Asia Studies, 57/2, 2005, 209-290.

${ }^{29}$ Vendil Pallin and Westerlund, 'Russia's War', 401.

${ }^{30}$ Roger McDermott, 'Network-centric Warfare as the Undeclared Aim of Russian Defense Reform', in McDermott et. al. (eds.), The Russian Armed Forces in Transition.

${ }^{31}$ Keir Giles quoted in Jonathan Marcus, 'Ukraine Crisis: Is Russia Ready to Move into Eastern Ukraine?', BBC News website, $8^{\text {th }}$ April 2014. http://www.bbc.co.uk/news/world-europe-26940375 (accessed 11th April 2014).

32 Blank 2012, pp. 159-162.

33 Klein, 'Towards a "New Look"', 43.

${ }^{34}$ Barany, 'Defence Reform', 49.

${ }^{35}$ Klein, 'Towards a "New Look"', 43.

${ }^{36}$ DeHaas, 'Russia's Military Doctrine', 54.

${ }^{37}$ ibid., 34.

${ }^{38}$ Mats Berdal, 'The “New Wars” Thesis Revisited' in Hew Strachan and Sibylle Scheipers (eds.), The Changing Character of War (Oxford: Oxford University Press 2011), 109-10.

${ }^{39}$ Hew Strachan and Sibylle Scheipers, 'Introduction: the Changing Character of War' in Strachan and Scheipers (eds.), The Changing Character of War, 18-20.

${ }^{40}$ Hew Strachan, 'Strategy in the Twenty-First Century', in Strachan and Scheipers (eds.), The Changing Character of War, 513.

${ }^{41}$ Gian P. Gentile, 'Let's Build an Army to Win all Wars', Joint Force Quarterly, 52/1, $2009,31$.

${ }^{42}$ Christopher Dandeker, “From Victory to Success: the Changing Mission of Western Armed Forces' in Jan Angstrom and Isabelle Duyvesteyn (eds.), Modern War and the Utility of Force: Challenges, Methods and Strategy (London: Routledge 2010), 24.

${ }^{43}$ Gentile, 'Let's Build an Army', 31. 
${ }^{44}$ The main tasks of the Russian armed forces during peacetime are listed in section III point 27 of the 2010 military doctrine. These are of a defensive nature, bar the provision of their use to protect Russian Federation citizens abroad from armed attacks; in peacekeeping operations under UN mandate; and in a range of 'military operations other than war', such as counter-piracy and disaster management. Russia's 2013 foreign policy concept reconfirms its opposition to armed humanitarian intervention and the 'responsibility to protect' (section III point 31).

${ }^{45}$ Graeme Herd, 'Security Strategy: Sovereign Democracy and Great Power Aspirations' in Mark Galeotti (ed.) The Politics of Security in Modern Russia, Farnham: Asghate, 2010, pp. 10-15.

${ }^{46}$ Russia's 2010 Military Doctrine, section I point 6, distinguishes between local wars, regional wars and large-scale wars.

${ }^{47}$ Ruslan Pukhov, 'Russia's military-technical policy', Valdai Discussion Club website, 1 February 2012. Available at <http://valdaiclub.com/defense/37960.html> (last accessed 12 July 2012).

${ }^{48}$ Keir Giles, 'Russian Operations in Georgia: Lessons Identified Versus Lessons Learned' in McDermott et. al. (eds.), The Russian Armed Forces in Transition, 21.

${ }^{49}$ Margot Light, 'Post-Soviet Russian Foreign Policy: The First Decade' in Archie Brown (ed.), Contemporary Russian Politics: A Reader, Oxford: Oxford University Press, 2001, 423-226.

${ }^{50}$ Keir Giles, 'The Military Doctrine of the Russian Federation', Research Review, NATO Defense College, Rome, February 2010. Available at < http://www.conflictstudies.org.uk/files/MilitaryDoctrine_RF_2010.pdf> (last accessed 1 July 2011).

${ }^{51}$ Azar Gat, 'The Changing Character of War' in Strachan and Scheipers (eds.), The Changing Character of War, 45.

${ }^{52}$ Christopher Jehn and Zachary Selden, 'The End of Conscription in Europe?', Contemporary Economic Policy, 20/2, 2008, 93-94.

${ }^{53}$ Charles Moskos and James Burk, 'The Postmodern Military' in James Burk (ed.), The Military in New Times: Adapting Armed Forces for a Turbulent World (Boulder, CO: Westview 1994).

${ }^{54}$ Anna Leander, 'Drafting Community: Understanding the Fate of Conscription', Armed Forces and Society, 30/4, 2004, 572.

${ }^{55}$ Timothy Edmunds, 'What are the Armed Forces For? The Changing Nature of Military Roles in Europe', International Affairs, 82/6, 1061.

${ }^{56}$ Thornton, 'Military Modernisation', 3.

${ }^{57}$ Dale Herspring, 'Dedovshchina in the Russian Army: the Problem that Won't Go Away', The Journal of Slavic Military Studies, 18/4, 2005, 607-629.

${ }^{58}$ Spivak and Pridemore, 'Conscription and Reform', 41-2.

59 Margarete Klein, 'Towards a "New Look" of the Russian Armed Forces?' in McDermott et. al. (eds.), The Russian Armed Forces in Transition, 38.

${ }^{60}$ Rod Thornton, 'Russia's Conscription Problem', Russian Analytical Digest 116, 2012, 5-7.

${ }^{61}$ Bettina Renz, 'Civil-military Relations and Russian Military Modernization' in McDermott et. al. (eds.), The Russian Armed Forces in Transition, 204.

${ }^{62}$ Viktor Litovkin, 'Army Reform Continues to March Forward', Russia Beyond the Headlines, $22^{\text {nd }}$ February 2013. 
${ }^{63}$ Leander, 'Drafting Community', 593.

64 Josh Rogin, 'McChrystal: Time to Bring Back the Draft', Foreign Policy, $3^{\text {rd }}$ July 2012 (online edition).

${ }^{65}$ Hodgson, 'Is the Russian Bear Learning', 80-81.

66 Jim Nichol, 'Russian Military Reform and Defense Policy', US Congressional Research Service, Report No. R42006, August 2011, pp. 16-7.

${ }^{67}$ James S. Corum, 'No Simple Formula: the Use of Military Force in Counterinsurgency' in Angstrom and Duyvesteyn (eds.), Modern War and the Utility of Force, 159.

${ }^{68}$ Cited in Klein, 'Russia's Military Capabilities', 16.

${ }^{69}$ Rod Thornton, Organizational Change in the Russian Airborne Forces: The Lessons of the Georgian Conflict (Carlisle, PA: Strategic Studies Institute 2011), 29.

${ }^{70}$ Dandeker, 'From Victory to Success', 23-24.

${ }^{71}$ Deborah Avant and James Lebovic, 'U.S. Military Attitudes Towards Post-Cold war Missions', Armed Forces and Society, 27/1, 2000, 37-56.

${ }^{72}$ Volker Franke, 'The Peacebuilding Dilemma: Civil-Military Cooperation in Stability Operations', International Journal of Peace Studies, vol. 11, no. 2, 2006, pp. 5-25.

${ }^{73}$ Kevin D. Stringer, Military Organizations for Homeland Defense and Smaller-Scale Contingencies: A Comparative Approach, Westport (CT: Praeger Security International 2006), 152.

${ }^{74}$ Bettina Renz, 'The Russian Power Ministries and Security Services' in Graeme Gill and James Young (eds.), Routledge Handbook of Russian Politics and Society (London: Routledge 2012), 209-19. 